\title{
Analisis resepsi audiens remaja terhadap romantisme film Dilan 1990
}

\author{
Rivga Agusta ${ }^{1}$ \\ ${ }^{1}$ Universitas Amikom Yogyakarta, Yogyakarta, Indonesia
}

\begin{abstract}
ABSTRAK
Film Dilan 1990 dengan segmentasi remaja ini menimbulkan euforia di kalangan remaja Indonesia. Tema romantisme film Dilan 1990 yang mengangkat tentang kehidupan romantis remaja yang hidup di tahun 1990 mendapat respons yang beranekaragam dari penonton remaja di Indonesia. Di antaranya banyak yang menggunakan potongan adegan dalam film tersebut untuk dijadikan meme di media sosial dan bahkan menggunakan potongan dialog tokoh di dalamnya untuk berkomunikasi. Penelitian ini bertujuan untuk menganalisis resepsi audiens remaja yang hidup di era milenial sekarang ini terhadap romantisme remaja pada tahun 1990 yang diusung pada film Dilan 1990. Metode penelitian yang digunakan dalam penelitian ini adalah metode analisis resepsi yang dilakukan kepada lima orang informan remaja. Hasil penelitian menunjukkan terdapat beberapa pemaknaan audiens remaja terhadap romantisisme dalam film Dilan 1990. Hal-hal yang dimaknai sebagai romantisisme yang ada dalam film Dilan 1990 antara lain yaitu 'Bandung Sebagai Kota Romantis', 'Tangisan Tokoh Sebagai Wujud Kemurungan', 'Rindu itu Berat', 'Rasa Suka yang Meluap', dan 'Romantisme Unik dalam Kata-kata Tokoh'. Posisi pembacaan audiens remaja yang dominan adalah dominant-hegemonic position dan negotiated position. Pemaknaan romantisme oleh audiens remaja berdasar kedua posisi tersebut dipengaruhi faktor sosiologis dari setiap informan yang memiliki latar belakang era yang cukup berbeda dengan tema yang diangkat pada film Dilan 1990.
\end{abstract}

Kata-kata Kunci: Analisis resepsi; romantisme; film; Dilan 1990; audiens remaja

\section{Analysis of teenage audience reception of romanticism in Dilan 1990 Film}

\begin{abstract}
Dilan 1990 film with the segmentation of teenage audience created euphoria among Indonesian teenagers. The romantic theme of the Dilan 1990 film, which carried out a romantic life of adolescents who lived in 1990, received many teenagers'responses in Indonesia. Many of them use scenes from the film as memes on social media and even use dialogues from the movie characters to communicate. This research analysed teenage audiences' reception in the current millennial era towards teenagers' romanticism in the year 1990 that was carried in the Dilan 1990 film. The researcher conducted the reception analysis method and interviewed five teenage informants. The results showed several interpretations of the youth audience towards romanticism in the Dilan 1990 film. The things that were interpreted as romanticism in the 1990 film Dilan included 'Bandung As a City of Romance', 'Crying Figures as a Form of Gloom', 'Longing is Heavy', 'Overflowing Love ', and' Unique Romance in Character's Words'. The dominant teenage audience reading position was the dominanthegemonic position and negotiated position. The meaning of romanticism by a teenage audience based on these two positions was influenced by each informant's sociological factors who had a different background from the theme raised in the Dilan 1990 film.
\end{abstract}

Keywords: Reception analysis; romanticism; film; Dilan 1990; teenage audience

Korespondensi: Rivga Agusta, S.IP., M.A. Universitas Amikom Yogyakarta. Jl. Ring Road Utara, Ngringin, Condongcatur, Kec. Depok, Kabupaten Sleman, Daerah Istimewa Yogyakarta 55281.Email: rivgagusta@ amikom.ac.id 


\section{PENDAHULUAN}

Awal tahun 2018, Indonesia sempat diramaikan dengan fenomena "Dilan". Dilan 1990 adalah film drama remaja besutan sutradara Fajar Bustomi dan Pidi Baiq yang merupakan adaptasi dari novel karya Pidi Baiq sendiri berjudul "Dilan 1990”. Film yang tayang perdana pada 25 Januari 2018 ini meraup penonton sebanyak 6.315.096 pada masa tayangnya di bioskop-bioskop tanah air (Film Indonesia, 2018). Jumlah ini membuat Film Dilan 1990 menjadi film kedua terlaris di Indonesia sepanjang masa setelah Film Warkop DKI yang meraih 6.858.616 penonton pada tahun 2016 (Abdullah \& Permana, 2020).

Film Dilan 1990 dengan segmentasi masyarakat remaja ini menimbulkan euforia tersendiri di kalangan masyarakat remaja Indonesia. Hal ini terlihat dari antusiasme mereka terhadap film ini di berbagai media sosial. Tidak sedikit akun Instagram yang khusus mengunggah gambar maupun foto terkait dengan film tersebut seperti akun@ dilanku yang memiliki 480,3k pengikut, akun @ film.dilan.official dengan 277k pengikut, dan akun@film_dilan dengan 59,9k pengikut.

Berbagai respons masyarakat terlihat dari kolom komentar pada akun-akun Instagram tersebut. Di antaranya ada yang mengaku "baper" atau terbawa perasaan dengan adegan-adegan yang

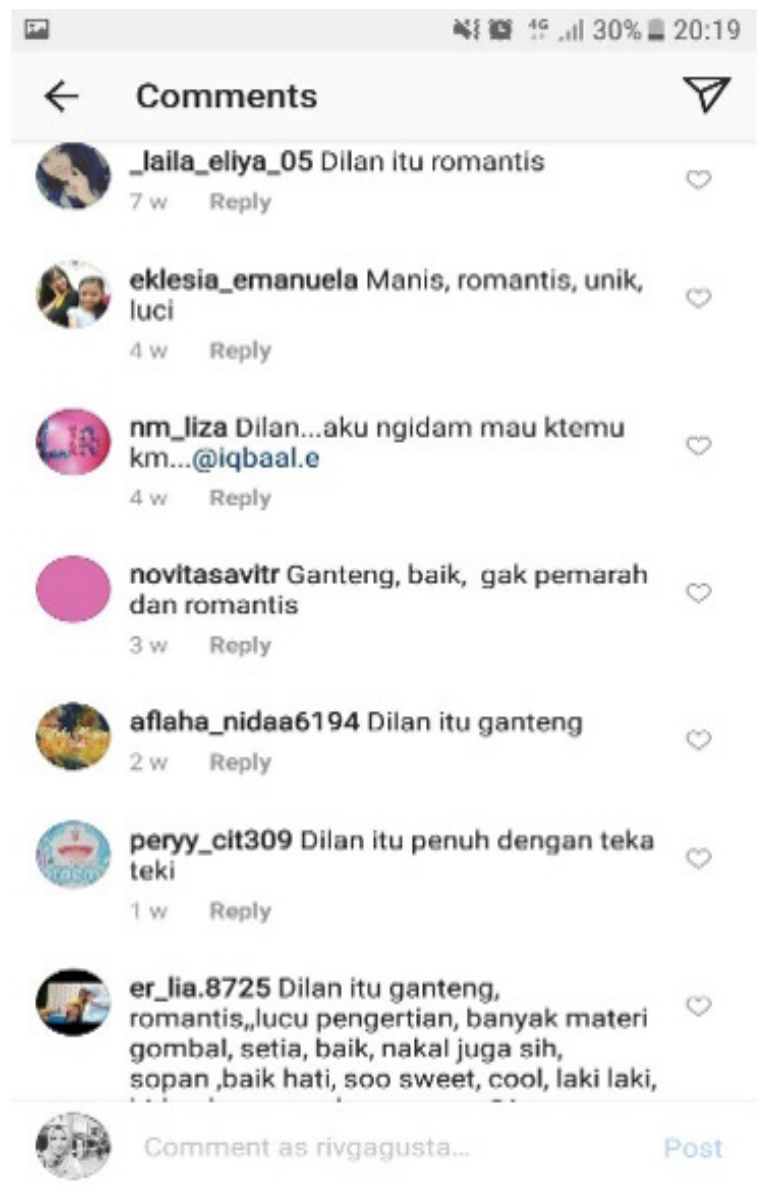

Sumber: Instagram, 2018

\section{Gambar 1 Respons positif Film Dilan 1990}

dilakukan Iqbal CJR sebagai pemeran Dilan.

Dari komentar-komentar pada akun Instagram tersebut terihat bahwa tidak sedikit dari mereka yang mengelu-elukan sosok romantis Dilan dalam film Dilan 1990. Namun demikian, terdapat juga respons mereka yang cenderung negatif dengan menunjukkan kekecewaan atas ketidaksesuaian cerita maupun pemeran yang diangkat dalam film.

Hal yang menarik dari euforia "Dilan" ini adalah tidak sedikit orang yang mengadaptasi dialog-dialog Dilan dalam film tersebut. Dialog Dilan dengan unsur romantis kepada tokoh 


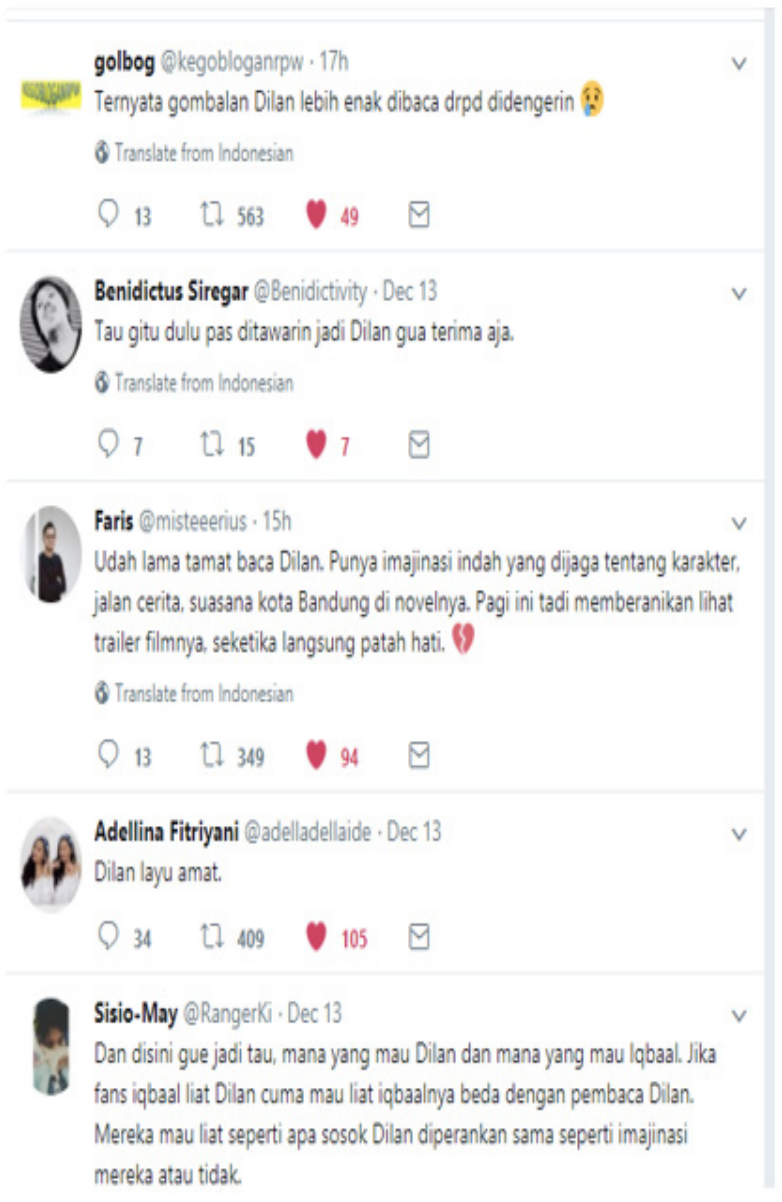

Sumber: Dagul, 2017

\section{Gambar 2 Respons negatif film Dilan 1990 di Twitter}

utama perempuan, Milea, merupakan dialog yang secara spesifik diadaptasi orang-orang. Adapun dialog yang dimaksud seperti "Jangan rindu. Ini berat, kau takkan kuat. Biar aku saja", atau "Milea, kamu cantik, tapi aku belum mencintaimu. Enggak tahu kalau sore. Tunggu aja." Uniknya, masyarakat tidak hanya secara gamblang menirukan dialog tersebut, tetapi juga memodifikasinya dengan berbagai penggantian istilah. Modifikasi dialog ini juga menjamur di berbagai media sosial.

Respons masyarakat baik yang menunjukkan rasa positif maupun negatif,

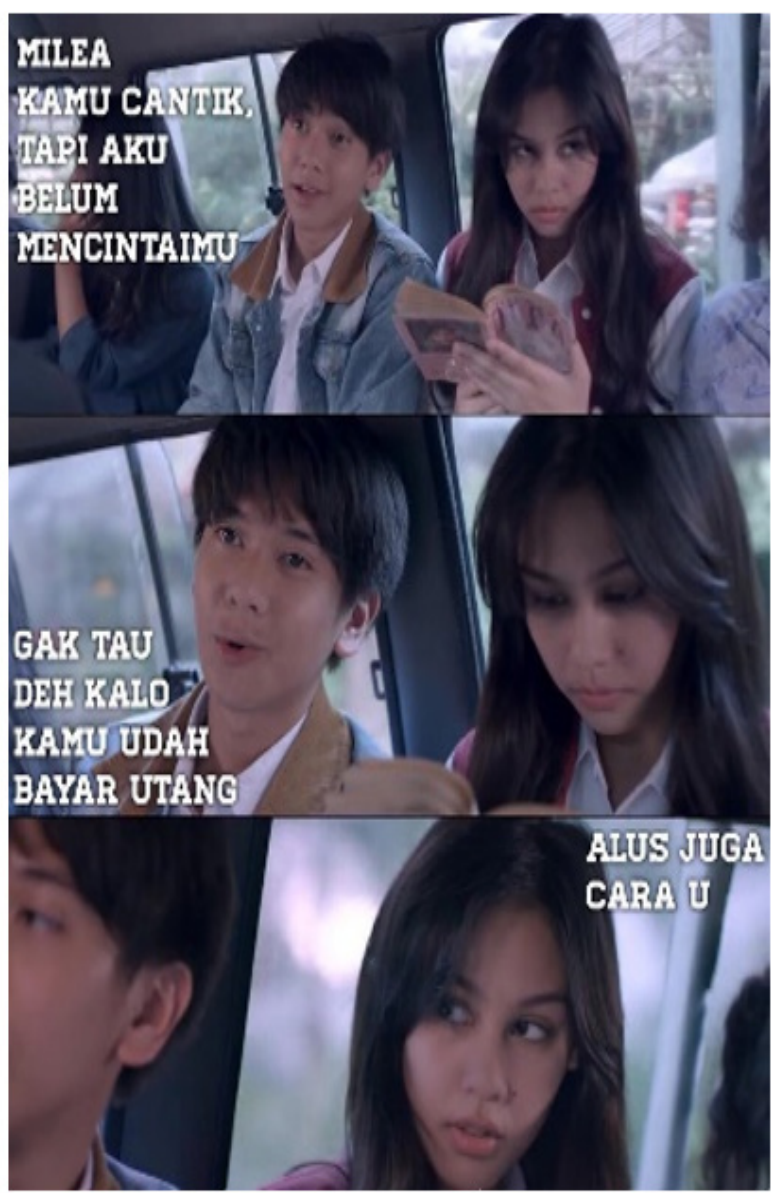

Sumber: Amalia, 2018

\section{Gambar 3 Modifikasi dialog Dilan}

hingga modifikasi dialog dalam film yang digunakan dalam komunikasi pada lingkup kehidupan sosial menunjukkan adanya banyak perbedaan interpretasi dari audiens film. Perbedaan interpretasi ini disebabkan oleh perbedaan latar belakang budaya, sosial, ekonomi, serta usia yang memengaruhi cara audiens meresepsi pesan-pesan yang terkandung dalam film.

Variasi interpretasi audiens atas sebuah film sebagai produk budaya populer memang sudah sewajarnya terjadi dalam komunikasi massa film. Seperti halnya pada Film Dilan 1990 yang 


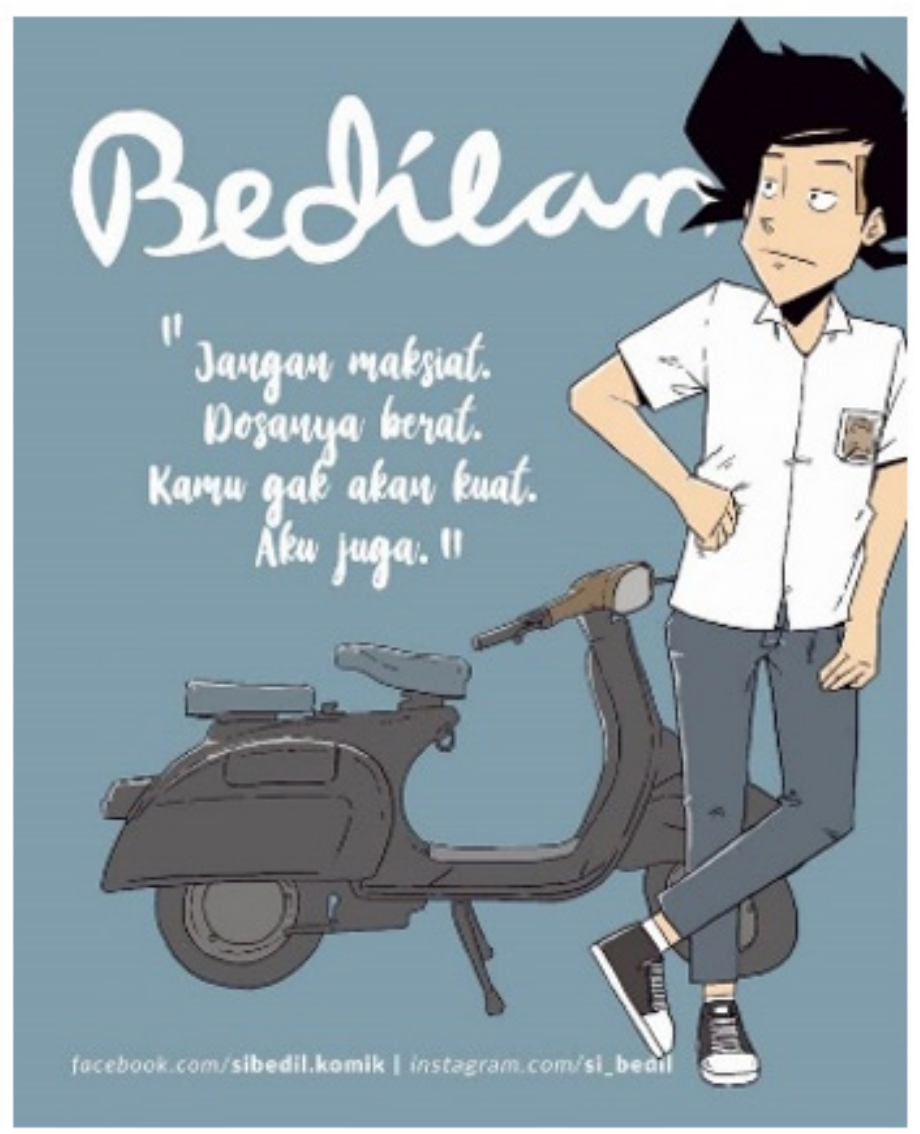

Sumber: Alit, 2018

\section{Gambar 4 Modifikasi dialog Dilan}

spesifik mengangkat cerita mengenai romansa anak SMA di tahun 1990, audiens remaja yang menjadi target dari film ini memiliki beragam interpretasi berdasar pada resepsi mereka atas pesan romantis film. Remaja juga rentan terpengaruh oleh promosi romantic beliefs atau keyakinan romantik dalam media karena remaja memiliki ketertarikan yang tinggi terhadap percintaan (Driesmans dkk., 2016). Ada di antara mereka yang ikut terenyuh dengan cerita remaja di tahun 1990-an tersebut meskipun memiliki setting kehidupan yang berbeda, yaitu di tahun 2018. Ada pula di antara mereka yang tergila-gila dengan sosok romantis
Dilan hingga berandai-andai memiliki kekasih seperti Dilan. Ada juga yang menggunakan kata-kata Dilan untuk diadaptasi baik dalam komunikasi interpersonal sehari-sehari, maupun dimodifikasi sebagai bentuk "pelesetan" atau lelucon.

Perbedaan interpretasi audiens remaja atas paparan pesan media perlu menjadi sorotan sebagai bentuk evaluasi atas pesan komunikasi massa film yang diterima audiens remaja. Khususnya pada film Dilan 1990 yang telah membius masyarakat dengan konten romantisnya. Remaja menggunakan film sebagai sumber informasi terakit perilaku dalam 
hubungan percintaan yang sukses dan model untuk refleksi diri (Johnson \& Holmes, 2009). Selain itu, konsumsi atas film akan membentuk ekspektasi terhadap hubungan percintaan yang terkadang mustahil (Vaterlaus dkk., 2018).

Riset terkait mengenai penerimaan audiens remaja atas film romantis Dilan 1990 juga dilakukan oleh Fais, dkk. (2019). Dalam penelitian tersebut dikaji mengenai persepsi remaja terhadap romantisme film Dilan 1990 dan ditemukan bahwa dalam segi hal romantis, faktor artis dan gaya penampilannya menjadi salah satu faktor dominan yang membuat remaja tertarik dengan film tersebut hingga meniru perilakunya. Selain itu, dalam riset analisis resepsi remaja yang dilakukan Briandana (2016), ditemukan bahwa audiens menggunakan hasil menonton untuk membangun identitas dirinya dan proses menonton menjadi sebuah upaya eksplorasi untuk mencari informasi serta pemahaman yang mendalam.

Mengacu pada kedua penelitian di atas, audiens dipandang aktif dalam memaknai pesan dari media yang dikonsumsi. Hal tersebut dikuatkan dengan pandangan Gumelar (2018) dalam riset analisis resepsi yang dilakukannya bahwa makna dari sebuah media bukanlah suatu hal yang tetap atau melekat pada teks, melainkan teks media mendapatkan makna hanya pada saat penerimaan (resepsi), yaitu pada saat mereka dibaca, dilihat, dan didengarkan. Lebih lanjut
Gumelar (2018) menerangkan bahwa penonton adalah produser makna dan bukan hanya konsumer konten media. Penonton atau audiens akan melakukan intepretasi teks media dengan keadaan yang sesuai dengan kehidupan sosial dan latar belakang budaya, serta pengalaman subjektif mereka.

Dengan segmentasi penonton remaja, perlu kiranya dilakukan analisis mengenai resepsi remaja terhadap pesan romantis yang secara khusus diangkat dalam film Dilan 1990 dan juga bagaimana posisi remaja sebagai audiens aktif dalam meresepsi film ini. Maka dari itu, dapat dikaji secara spesifik bagaimana pesanpesan romantisme tersebut diterima oleh audiens remaja. Analisis kepada audiens ini dilakukan untuk mengkaji resepsi remaja di tahun 2000-an sebagai audiens film dengan setting tahun 1990-an. Penelitian ini dilakukan dengan tujuan untuk mengetahui resepsi dari remaja dengan latar belakang kebudayaan yang berbeda sebagai audiens aktif film Dilan 1990.

\section{METODE PENELITIAN}

Penelitian ini dilakukan menggunakan pendekatan kualitatif. Penelitian kualitatif merupakan salah satu metode penelitian yang bertujuan untuk mendapatkan pemahaman tentang kenyataan melalui proses berpikir induktif. Merujuk pada fenomena dalam permasalahan yang diusung, yakni mengenai 
perbedaan audiens dalam meresepsi pesan, maka peneliti menggunakan metode analisis resepsi (reception analysis). Analisis resepsi yaitu metode yang bercirikan keterlibatan langsung di lapangan sehingga memungkinkan peneliti menjadi tidak berjarak dengan objek penelitian. Analisis resepsi merupakan salah satu fokus studi yang mempelajari audiens aktif. Metode analisis resepsi memandang audiens sebagai producer of meaning yang aktif menciptakan makna, bukan hanya sebagai konsumen dari isi media (Fathurizki \& Malau, 2018).

Melalui metode analisis resepsi, peneliti dapat melihat secara langsung bagaimana audiens meresepsi pesan dalam film Dilan 1990. Peneliti menggunakan analisis resepsi untuk melihat penerimaan remaja atas pesan romantisme yang terkandung dalam film Dilan 1990 berdasar perbedaan latar belakang sosiokultural informan.

Latar belakang sosio-kultural yang memengaruhi perbedaan interpretasi pesan oleh audiens menjadi landasan riset khalayak dalam studi kultural. Stevenson (2002) menerangkan bahwa isi pesan (meanings) yang di-encodingkan melalui kerangka berpikir memiliki dimensi sosial dan material yang dikelilingi oleh proses-proses sosial ekonomi dalam masyarakat. Isi pesan dibentuk oleh pemirsa pesan yang melakukan decoding atas pesan dalam konteks berpikir mereka masing-masing.
Perbedaan dalam latar belakang seperti latar belakang masa, tempat geografis, dan kondisi sosial memengaruhi kesamaan antara pesan yang di-encoding dan pesan yang di-decodingkan. Kode memiliki bermacam jenis di mana isi pesan dikonstruksikan dapat berbeda dari satu interpretasi yang lain dan tentu saja dapat pula berbeda antara pengirim maupun penerima (atau lebih tepatnya dari encoder kepada decoder).

Model encoding-decoding tersebut menegaskan bahwa pesan yang disampaikan pengirim tidak diterima secara pasif oleh audiens. Hall lebih mendalami model komunikasi encoding-decoding dengan melihat wacana penuh makna dalam suatu pesan yang diencoding-kan menurut struktur pengertian dari organisasi produksi pesan dan pendukungnya, di-decoding-kan menurut struktur pengertian dan kerangka pengetahuan yang berbeda-beda situasinya pada setiap audiens (Stevenson, 2002).

Untuk mendalami subjektivitas audiens dalam melakukan proses konstruksi makna teks media ini, maka dilakukan kajian mengenai interpretasi audiens. Kajian ini cukup banyak dilakukan, salah satunya oleh Yoo dan Buzinde (2012). Yoo dan Buzinde (2012) menjelaskan bahwa interpretasi audiens dapat dipahami melalui teori resepsi atau teori penerimaan audiens. Lebih lanjut dijelaskan, resepsi merupakan interaksi antara khalayak dan pesan 
media secara keseluruhan (Yoo \& Buzinde, 2012). Teori ini digunakan untuk memeriksa mekanisme produksi makna audiens terkait dengan teks media, seperti film atau program televisi.

Mengacu gagasan Hall bahwa dengan analisis resepsi ini, dapat diketahui bagaimana penonton membangun gagasan yang terbentuk sebelumnya dan posisi budaya dalam proses penerimaan untuk menyetujui, bernegosiasi, atau menantang isi teks pesan (Yoo \& Buzinde, 2012). Hal ini menekankan bahwa penonton atau audiens secara aktif melakukan penerimaan pesan dari media yang dikonsumsi.

Adapun konsep audiens aktif yang ditawarkan oleh Stuart Hall tersebut dikembangkan menggunakan audiens media massa televisi sebagai objek kajiannya. Hall mengajukan tiga hipotesis tentang proposisi audiens dalam meresepsi pesan. Ketiga proposisi audiens tersebut yaitu DominantHegemonic Position, Negotiated Position, dan Oppositional Position (Davis, 2004).

Dalam posisi Dominant-Hegemonic Position, audiens mengambil arti sepenuhnya dari apa yang terdapat dalam kerangka interpretasi yang diusulkan dan dirujuk oleh pesan itu sendiri. Maka audiens membaca pesan dari posisi yang sama seperti dengan posisi pembicara atau media yang menyampaikan pesan.
Audiens dalam posisi Negotiated Position dapat mengambil makna secara umum seperti disandikan dalam pesan. Dalam beberapa konteks konkret ataupun situasional yang mencerminkan posisi dan kepentingannya, pembaca memodifikasi atau mengubah sebagian makna yang dirujuk oleh pesan, sehingga audiens dapat membaca pesan dan menerima stuktur dasar dari pesan yang disampaikan. Namun audiens tetap melakukan negosiasi terhadap detail-detail pesan yang lain.

Pada Oppositional Position, audiens dapat mengenali bagaimana pesan tersebut telah disandikan secara kontekstual, tetapi audiens lebih mengedepankan alternatif pada pemaknaan pesan, yaitu sebuah interpretasi yang secara langsung beroposisi dengan makna yang dirujuk oleh pesan. Maka audiens membaca pesan dari posisi dan kerangka pikir yang sama sekali berbeda dengan posisi dan kerangka pikir pembicara atau media penyampai pesan.

Metode analisis resepsi melibatkan khalayak sebagai partisipan aktif dalam melakukan interpretasi makna dari teks yang mereka baca. Apa yang ditampilkan media akan dipahami sebagai sebuah proses yang masuk akal dan dikonstruksi melalui pembacaan gambar dan teks. Pemaknaan akan teks dan gambar tersebut adalah produk interpretasi dari penonton itu sendiri (Hardyanti, 2019).

Terdapat tiga elemen dalam reception 
analysis, yaitu mengumpulkan, menganalisis, dan menginterpretasikan data (Jensen, 2013). Hal pertama yang dilakukan adalah mengumpulkan data berupa kata, frasa, maupun kalimat yang diungkapkan oleh audiens, yakni dengan wawancara, observasi, dan kritik teks. Kedua, menganalisis hasil wawancara audiens dengan menganalisis wacana yang muncul melalui penarikan kutipan yang menyolok. Ketiga, menginterpretasikan pengalaman/ penerimaan audiens tentang media dengan referensi konstan pada konteks wacana media dan juga pada konteks sosial umum.

Melalui pendekatan analisis resepsi peneliti dapat melihat mengapa audiens memaknai sesuatu secara berbeda serta faktor-faktor psikologis dan sosial apakah yang kemudian akan muncul dalam bentuk pemikiran. Faktor psikologis yang akan memengaruhi pemikiran audiens dapat meliputi faktor kedekatan atas media yang digunakan maupun materi pesan dalam Film Dilan 1990. Sedangkan faktor sosial yang melingkupi para audiens dalam melakukan pemaknaan pesan dapat meliputi latar belakang sosial mereka selama ini.

Subjek dalam penelitian ini adalah audiens penonton Film Dilan 1990. Audiens ini terdiri dari para remaja yang merupakan siswa dari SMA Negeri 11 Yogyakarta. Adapun siswa yang dipilih sebagai informan dalam penelitian ini berjumlah lima orang yang terdiri dari dua siswa laki-laki dan tiga siswa perempuan. Kelima siswa berasal dari komunitas internal sekolah yang berbeda berdasar pada ekstrakurikuler yang mereka ikuti yaitu ekstrakurikuler teater, orkestra, olahraga, fotografi, dan OSIS.

Pengumpulan data dilakukan dengan indepth interview untuk memperoleh informasi yang lebih mendalam terdapat satu jenis khusus wawancara, yakni wawancara mendalam atau indepth interview. Dari wawancara mendalam akan didapatkan pemahaman mengenai pandangan, sikap, tanggapan, opini, serta perasaan audiens pada Film Dilan 1990. Terutama akan didapatkan data mengenai makna yang dibentuk oleh audiens dan kesesuaiannya dengan makna yang diinginkan muncul oleh pembuat pesan.

Dari data yang dapatkan, peneliti melakukan analisis data dari kelima informan. Peneliti melakukan reduksi data dengan memilih catatan-catatan tertulis di lapangan. Reduksi data dilakukan dengan memilih bagian-bagian mana yang dikode, membuang data, membuat pola-pola untuk meringkas bagian-bagian yang tersebar, dan mengungkapkan cerita yang sedang berkembang. Kemudian peneliti melakukan pengelompokkan posisi pembacaan audiens terhadap teks media menurut Stuart Hall antara lain dominant atau hegemonic reading, negotiated reading, dan oppositional hegemonic. 


\section{HASIL DAN PEMBAHASAN}

Terdapat beberapa pemaknaan audiens remaja terhadap romantisisme dalam film Dilan 1990. Hal-hal yang dimaknai sebagai romantisisme yang ada dalam film Dilan 1990 antara lain yaitu 'Bandung sebagai Kota Romantis', 'Tangisan Tokoh sebagai Wujud Kemurungan', 'Rindu itu Berat', 'Rasa Suka yang Meluap', dan 'Romantisme Unik dalam Kata-kata Tokoh'.

Romantisisme dibangun dari suasana keadaan alam sebagai latar penceritaan yang mendukung perasaan hari karakter dalam cerita. Seperti pada konsep romantisisme Neyos meliputi pada konsep romantisme "Kembali ke Alam" (Pratiwi dkk., 2013).

Konsep ini berpandangan bahwa alam adalah sesuatuyang mendukung dan menentukan perasaan hati manusia. Alam menggambarkan periode romantik, perumpamaan, ide, dan metafora (Efsa, 2015). Maksud dari pandangan ini adalah perasaan hati manusia tergantung pula dari bagaimana keadaan alam di sekitarnya. Alam memiliki pengaruh besar pada pengarang beraliran romantis. Seperti kesunyian desa di malam hari sebagi bagian dari keindahan alam dapat memberi motif romantis dalam sebuah suasana cerita. Konsep kembali ke alam merupakan ciri khas yang direpresentasikan dalam sebuah kondisi latar lokasi atau keadaan alam latar penceritaan yang mendukung perasaan hati karakter dalam cerita.

Dalam hal ini, kelima informan memiliki pemaknaan bahwa lokasi yang menjadi latar kisah Dilan dan Milea, yakni Kota Bandung memiliki kesan romantis. Hal ini diungkapkan oleh informan IV dan informan I sebagai berikut "Romantis sih kayak, Bandung tu dari film yang aku liat tu kayak sejuk. Keliatan banget kaya tempatnya sejuk terus apa sih kayak apa ya itu kan kayak masa lalu banget kan kayak old school gitu kan ceritanya tahun 1990 terus kesan masa lalunya juga kerasa sih kayak kalo buat setting-nya bagus" Fransisco

"Iya si, pas yang di daerah rumahnya Milea gitu. Rumahnya Milea, rumahnya Dilan kan kayak masih emang, romantis aja sih tempatnya kayak masih jaman dulu. Di jalan-jalan depan rumahnya. Enak aja gitu kan tempatnya kayak yang nyaman gitu." - Alika

Romantisme yang dibangun Kota Bandung di sini ditekankan pada suasana kuno yang sesuai dengan latar waktu tahun 1990 di mana kisah Dilan dan Milea berada. Dalam film, Bandung menjadi lokasi sentral yang selalu disebut dalam penceritaan narator tokoh Milea karena kota ini adalah tempat benihbenih cinta Milea dan Dilan bermula. Dalam pemaknaan unsur romantisme alam, di mana Bandung disimpulkan sebagai Kota Romantis, para informan berada pada posisi negotiated. Pada posisi ini, informan mengambil makna secara umum seperti disandikan dalam pesan 
yaitu Bandung sebagai kota sentral romantis, tetapi informan memodifikasi atau mengubah sebagian makna yang dirujuk oleh pesan.

Romantisme kota Bandung yang dimaknai informan tidak mengacu pada kota bersejarah bagi kisah cinta Milea dan Dilan sebagaimana Milea menarasikan kisahnya bersama Dilan di kota tersebut, tetapi informan memaknai Kota Bandung sebagai kota romantis karena suasana, bangunan, dan latar kuno yang disajikan dalam visual kota tersebut. Hal ini menunjukkan bahwa informan menggunakan beberapa konteks konkret ataupun situasional yang mencerminkan posisi dan kepentingannya, yakni memaknai Kota Bandung yang romantis karena suasanya bukan sebagai kota bersejarah bagi kisah cinta Milea dan Dilan. Dalam posisi negotiated ini, informan membaca pesan dan menerima stuktur dasar dari pesan yang disampaikan, tetapi audiens tetap melakukan negosiasi terhadap detail-detail pesan yang lain. Hal ini dikarenakan referensi Kota Bandung yang diacu oleh para informan adalah suasana kuno yang tampak secara visual saja dan bukan dikarenakan aspek sejarah kisah cinta tokoh utama.

Padakonsep romantisme, 'Kembali ke alam' yang dipaparkan Fitrianingsih dan Nazaruddin (2017) disimpulkan sebagai besarnya pengaruh alam terhadap tokoh utama. Alam merupakan tempat meluapkan emosi tokoh. Selain itu, alam merupakan pendukung perasaan atau suasana hati manusia yang diakibatkan oleh luapan perasaan berlebihan. Alam digunakan sebagai tempat pelarian dalam menyalurkan segala sesuatu yang menyesakkan hati. Konsep ini tidak dimaknai sama secara menyeluruh oleh para informan. Pemaknaan Bandung Kota Romantis ditunjukkan dari bagaimana informan memandang suasana nyaman dan sejuknya kota Bandung itu sendiri yang disajikan secara visual oleh sineasnya. Sehingga dalam pemaknaan ini dapat dikatakan bahwa romantisisme 'kembali ke alam' bisa muncul tidak hanya sebagai tempat dimana tokoh meluapkan emosinya tetapi sebagai tempat yang dirasa nyaman oleh audiens itu sendiri. Romantisme yang dirasakan audiens remaja pada sebuah lokasi cerita terbangun karena pengalaman referensi kenyamanan audiens terhadap tempat tersebut.

Romantisisme dicirikan dengan adanya suasana 'kemurungan'. Kemurungan atau melankolis digambarkan sebagai perasaan suram dari seorang karakter dalam cerita (Pratiwi dkk., 2013). Perasaan suram dapat ditunjukkan dengan kekecewaan, kesedihan, kehilangan, atau rasa sakit (Wolfson, 2014). Informan memaknai unsur kemurungan ini dalam adegan Milea terlihat cemas karena Dilan perlahan menjauhi Milea setelah mereka bertengkar. Hal ini menujukkan rasa sedih dan kehilangan. Kemurungan pada adegan ini 
dimaknai sama oleh informan I, II, III, dan V.

Seperti yang disampaikan informan I:

“... pas Dilan jauhin Milea. Waktu si ketua kelasnya Milea ngedeketin si Milea terus kan jadi deket banget. Dilan kan mikir Milea udah sama si ketua kelasnya terus Dilan jauhin. Mileanya sedih kan Dilan berubah jadi cuek kan. Terus Milea jadi kayak yang kesepian gitu... jadi kepikiran terus. Kayak Mileanya tu nggak sadar kalo dia cemas ke Dilan tapi Dilannya tuh kayak ngejauh gitu loh." - Alika

Dalam kemurungan, seorang karakter melakukan perenungan dalam ketenangan.

Tema kemurungan dalam kesusastraan biasanya dimunculkan akibat kebencian, cinta yang tidak bahagia, penderitaan hidup, dan hal-hal yang tidak menyenangkan yang mengganggu perasaan. Menurut pernyataan Informan I, kondisi ini juga dialami oleh tokoh Milea saat berada di perjalanan di bus, sesaat setelah Milea putus dengan pacarnya. Informan I menyatakan bahwa Milea merasa direndahkan oleh pacarnya dan teringat Dilan yang tidak ada untuk melindunginya. Hal ini Informan I tangkap dari kata-kata Dilan kepada Milea sebelumnya bahwa jangan sampai ada yang menyakiti Milea. Kemurungan ditunjukkan dari bagaimana Milea melakukan perenungan atas perkataan seseorang dan kejadian buruk yang telah menimpanya.

"Yang pas ini Mileanya nangis-nangis garagara tau Dilannya jalan sama Susi apa ya, siapa sih? Ah pokoknya itulah. Mileanya nangis-nangis di kamar gitu... nggak, nggak banget sih tapi kayanya sedih kalo buat Mileanya sih... gara-gara dia nangis- nangis... iya yang Mileanya nangis-nangis gitu, nangis-nangis di kamar, ya gitu deh. Sama yang ini Mileanya ditampar. Garagara itu kan Mileanya nyari siapa ya, Mileanya nyari Dilan ke warung apa gitu yang di situ ada temen-temennya si Dilan terus sama temennya si Dilan tu Mileanya tu malah di kayak digodain apa pokoknya kayak dijawab gitu tapi cuma dijawab asal ngawur gitu terus sama temennya tuh malah ditampar gitu. Terus Mileanya langsung lari, nangis, nangis-nangis, terus nangis di kelas gitu. Sedihnya." - Fransisco

Unsur kemurungan yang diungkap oleh Informan IV yakni dalam adegan Milea menangis karena Dilan pergi jalan dengan Susi serta adegan di mana Milea menangis setelah ditampar oleh teman Dilan di warung. Dalam memaknai unsur kemurungan dalam film Dilan 1990 ini, audiens remaja berada pada dominant-hegemonic position. Pada posisi ini, audiens mengambil arti sepenuhnya dari apa yang terdapat dalam kerangka interpretasi yang diusulkan dan dirujuk oleh pesan itu sendiri. Seperti adegan menangis yang disebabkan hal-hal yang menyakitkan tokoh dibaca secara penuh sebagai sebuah kemurungan oleh audiens remaja. Maka audiens membaca pesan dari posisi yang sama seperti dengan posisi pembicara atau media yang menyampaikan pesan.

Pemaknaan romantisme yang ketiga adalah pemaknaan unsur primitivisme. Pratiwi, dkk. (2013) menjelaskan bahwa primitivisme merupakan unsur romantisisme yang ditandai 
oleh kerinduan masa lalu dan kejayaan di masa yang akan datang. Kerinduan masa lalu umumnya digambarkan dalam aspek penceritaan karakter yang mengingat kembali kejadian-kejadian yang telah dilalui bersama dengan pasangan romantisnya atau sosok yang dirindukan. Aspek kejayaan di masa yang akan datang merupakan penceritaan karakter yang mendambakan sebuah akhir yang bahagia.

Unsur primitivisme yang paling menonjol dalam pemaknaan para informan adalah perasaan kerinduan yang diekspresikan para tokoh di dalam film. Kerinduan masa lalu umumnya digambarkan dalam aspek penceritaan karakter yang mengingat kembali kejadian-kejadian yang telah dilalui bersama dengan pasangan romantisnya atau sosok yang dirindukan. Secara khusus, pemaknaan atas kerinduan dimaknai oleh para informan berdasar kata-kata Dilan yaitu "Jangan rindu, rindu itu berat, biar aku saja”. Hal ini diungkapkan oleh informan I dan V:

"Yang kalo nggak salah, Milea sih yang bilang rindu. Terus Dilan bilang "jangan rindu, rindu itu berat'. Yang pas ditelepon." - Alika

"Aaa, karna keliatan tu karna Dilannya bilang 'jangan rindu'. Kan keliatan banget kalau Mileanya juga kangen. " - Hilal

Selain itu, aspek kerinduan juga dimaknai audiens dari adegan Milea dan Dilan yang masih saling curi pandang di sekolah setelah mereka bertengkar seperti yang diungkap oleh informan III. Menurut informan III, tindakan Milea yang curi-curi pandang menandai bahwa Milea merindukan sosok Dilan.

"Terus, mungkin curi-curi pandangnya tuh nandain kalok Mileanya tuh kangen sama sosok Dilan yang dulu pas dia marahan. Terus Dilannya kan kayak pura-pura buang muka gitu kan." - Sang Ayu

Pemaknaan primitivisme kerinduan para informan di sini menunjukkan posisi audiens remaja pada posisi yang sama dengan kerangka interpretasi yang ditawarkan cerita yaitu dominant-hegemonic position. Adapun kerangka interpretasi yang ditawarkan secara harfiah tersampaikan dalam dialog yang mengandung unsur kata-kata 'rindu'.

Meskipun pemaknaan kerinduan semua informan memiliki kesamaan pada kata-kata harfiah 'rindu' tersebut, tidak semua informan memaknai unsur kerinduan yang justru menyelimuti keseluruhan inti cerita film Dilan 1990. Aspek inti kerinduan yang dimaksud adalah teknik penceritaan utama dengan menggunakan sudut pandang Milea pada film ini yang menceritakan kisah masa lalunya ketika dia sudah dewasa dan menikah. Adegan kunci yang menunjukkan kerinduan ini justru terlihat pada bagian pembuka film dimana sosok Milea dewasa yang telah menikah mengawali film Dilan 1990 ini. Kedua audiens laki-laki, yakni informan IV dan V, serta satu audiens 
perempuan, yakni informan I, memaknai cara Milea menceritakan kisahnya dengan Dilan di awal film merupakan bentuk dari kerinduan yang dialami tokoh. Perbedaan posisi ini dikarenakan kedua informan lainnya yang tidak cukup yakin mengingat adegan tersebut pada bagian awal film.

Romantisme mengandung unsur sentimentalis. Pratiwi, dkk (2013) memaparkan bahwa sentimentalis merupakan deskripsi tentang ungkapan emosi secara berlebihan atas sesuatu yang disukai, seperti suka akan kelembutan dan keintiman. Sentimentalis dapat digambarkan dengan ekspresi yang menunjukkan kegandrungan akan sifat alamiah yang semuanya lebih bersifat patetis dari pada etis.

Unsur sentimentalis pada romantisme film ditunjukkan dari ungkapan emosi tokoh secara berlebihan atas sesuatu yang disukai. Pada film Dilan 1990, bisa dikatakan sepanjang film menceritakan bagaimana rasa suka antara Dilan dan Milea. Informan pada penelitian ini memaknai rasa suka antara kedua tokoh tersebut berdasar beberapa adegan inti antara lain pada adegan Milea secara sungguh-sungguh melarang Dilan ikut tawuran dengan temantemannya. Seperti yang diungkap informan I berikut:

"...yang pas Dilan mau tawuran yang pas dikasih tau sama temennya, siapa ya.. lupa temennya siapa terus pokoknya yang Milea bener-bener nyegah Dilan buat pergi. Sampek kan abis itu kan, abis Milea denger berita itu kan ke rumahnya Dilan terus bener-bener Dilan.. Milea tu ngalangin Dilan. Kek 'mau kemana, aku ikut'. Jangan sampek Dilan pergi. Terus yang pas di sekolah yang dilemparin batu terus Milea sampek bener-bener nekat larilari di lapangan padahal tu lapangannya dilemparin batu demi nyariin Dilan." Alika

Resepsi audiens pada adegan ini menunjukkan informan berada pada posisi dominant-hegemonic, yang mana informan meresepsinya sesuai dengan ekspresi emosional tokoh Milea yang sangat khawatir kepada Dilan apabila terjadi hal buruk kepadanya. Kekhawatiran semacam ini adalah bentuk dari rasa suka yang meluap antara tokoh. Selain adegan ini, informan memaknai sentimentalis pada adegan Dilan berkelahi dengan Anwar karena telah menampar Milea. Menurut informan I dan $\mathrm{V}$, adegan ini menunjukkan bahwa Dilan memiliki perasaan sayang kepada Milea karena sampai berkelahi dengan sahabatnya sendiri demi melindungi Milea.

"Yang pas Dilan berantem sama Anwar. Yang pas Milea dijelek-jelekin sama Anwar terus Dilan jadi berantem sama Anwar. (Menurutmu itu cara apa?) caranya Dilan buat ngelindungin Milea terus nunjukin kalok sebenernya dia sayang sama Milea. (Selain itu) paling sama kayak yang Cuma becanda-becanda, gombal-gombalannya." - Alika

"Terus juga ada bagian yang dia ngelindungin, Dilan ngelindungin Milea... kan pas Milea di tampar kan Dilan langsung nggak nerima tho."- Hilal 
Cara Dilan melindungi Milea hingga menyakiti sahabatnya sendiri merupakan wujud sentimentalis yang digambarkan dengan ekspresi yang menunjukkan kegandrungan akan sifat alamiah yang semuanya lebih bersifat patetis dari pada etis. Hal ini dikarenakan Dilan yang secara emosional mengekspresikan amarahnya sehingga mengesampingkan hubungan persahabatannya daripada rasa sayangnya kepada Milea.

Pemaknaan romantisisme di sini dibangun dari cerita yang dahsyat dan emosional. Dahsat merupakan kondisi yang unik dan tidak biasa dialami sebagian besar orang, sehingga aspek ini mendorong kondisi emosional tokohnya. Emosional sendiri merupakan keadaan yang ditimbulkan oleh situasi tertentu atau khusus dan berlangsung pada waktu yang relatif singkat seperti yang dilakukan Dilan ketika memukul Anwar sebagai bentuk gejolak perasaan tokoh dalam film.

Selain romantisme pada adegan perkelahian dan kekhawatiran Milea terhadap Dilanyang ikut tawuran, informan meresepsi adegan kedekatan Milea dengan keluarga Dilan, adegan Dilan mendekati Milea pertama kali saat berjalan kaki, dan adegan Milea berusaha menjelaskan hubungannya dengan Kang Adi kepada Dilan sebagai bentuk rasa sayang antara kedua tokoh. Posisi audiens pada penerimaan pesan adegan ini berada pada dominant-hegemonic position. Audiens meresepsi segala emosi rasa sayang yang meluap antara Dilan dan Milea sebagaimana gejolak percintaan antara kedua tokoh tersebut terbangun dalam film. Para informan tidak melihat adegan-adegan tersebut sebagai kondisi yang tidak biasa bagi remaja yang sedang kasmaran atau jatuh cinta, karena mereka memilik pandangan bahwa sudah semestinya orang yang sayang berperilaku sebagaimana yang dilakukan Dilan dan Milea. Artinya, beberapa peristiwa sentimentalis yang ada pada latar cerita Dilan di tahun 1990 masih terasa relevan dengan kehidupan umumnya para remaja di era para informan seperti saat film ini tayang (tahun 2018).

Pemaknaan audiens remaja atas romantisme film Dilan 1990 yang terakhir berkaitan dengan unsur eksotisme. Fitrianingsih dan Nazaruddin (2017) menjelaskan bahwa eksotisme merupakan ciri romantisme yang lebih banyak diketahui oleh masyarakat di mana diketahui bahwa eksotisme dalam romantisme merupakan perlakuan yang dilakukan secara spontanitas dan penuh dengan luapan perasaan yang menggebu-gebu serta mengandung keunikan dan rasa asing yang mengandung daya tarik khas. Ciri romantisme ini adalah gambaran tentang perasaan yang dipengaruhi oleh emosi yang berlebihan yang dipengaruhi oleh keinginan-keinginan yang bersifat keindahan 
serta keunikan. Juniawati, dkk. (2019) menjelaskan secara spesifik bahwa eksotisme ini menyangkut sifat dan ciri latar, tokoh, serta peristiwa yang terasa asing dan unik.

Para informan dalam penelitian ini memaknai romantisme dalam film Dilan sebagai romantisme yang unik. Keunikan dalam romantisme Dilan dimaknai oleh para informan khususnya pada kosa kata yang digunakan Dilan dalam mengungkapkan kalimat "gombalan" atau pujian yang ditujukan untuk membuat Milea senang. Seperti yang dingkap Informan I, II, dan IV berikut:

"Apa ya. Ada yang pas Milea mau ke Jakarta. Yang pas dibilangin 'jangan sampe ada yang nyakitin. Kalo nggak, orang itu bakal hilang'." - Alika

"Mmm apa ya, oh yang ini yang teleponan terus 'jangan rindu, rindu berat' gitugitu kan lucu tuh. Oo yang, aduh ini tuh termasuk alay tapi romantis juga yang si ini Milea tu bilang apa, jangan.. apa kamu jangan ikutan genk motor lagi, gini..gini.. gini.. ke Dilan. Terus Dilannya bilang kalo misalnya dia ikut gimana, ntar si Mileanya bilang dia bakal ngilang dari bumi. Itu alay banget tapi lucu e." - Fransisco

Keunikan yang diterima informan dalam kata-kata yang digunakan Dilan kepada Milea mengusung unsur individualisme dan eksotisme dalam romantisme film Dilan 1990. Eksotisme dalam romantisme merupakan perlakuan yang dilakukan secara spontanitas dan penuh dengan luapan perasaan yang menggebu-gebu serta mengandung keunikan dan rasa asing yang mengandung daya tarik khas, di mana ciri romantisme ini gambaran tentang perasaan yang di pengaruhi oleh emosi yang berlebihan yang dipengaruhi oleh keinginan-keinginan yang bersifat keindahan serta keunikan.

Eksotisme dalam keunikan kata-kata Dilan tidak terlepas dari individualisme karena individualisme dan eksotisme adalah dua hal yang saling berkaitan dalam romantisisme. Eksotisme kata-kata Dilan merupakan perlakuan tokoh yang mengandung keunikan serta rasa asing yang mengandung daya tarik khas pada hal-hal yang bersifat aneh dan sangat indah. Eksotisme di sini merupakan wujud dari ekspresi tokoh yang merasakan romantisisme dengan merasakan kegaiban jarak seperti kata-kata kerinduan yang disampaikan Dilan dan Milea dalam perbincangan di telepon. Di dalamnya, perasaan masing-masing individu kedua tokoh tenggelam dalam keinginan-keinginan, emosi sangat dipengaruhi oleh imbauan sugesti dan misteri. Sehingga romantisme atas keunikan kata-kata Dilan dipandang audiens sebagai proses diri individu masuk ke dalam perasaan serta dunia mimpi mereka sendiri tetapi juga melakukan pencarian pengalaman emosional yang ada pada dunia eksternal: rasa rindu dan Milea.

Pemaknaan informan atas penggunaan kata-kata Dilan yang terasa unik, tetapi terasa beda dan lucu menunjukkan bahwa audiens 
remaja di sini berada pada posisi negotiated position. Meskipun audiens remaja merasakan keunikan atas eksotisme kata-kata Dilan, tetapi audiens remaja melihatnya sebagai sesuatu yang lucu dan berbeda dengan umumnya penggunaan kata-kata orang ketika melakukan "gombalan" atau pujian kepada seseorang yang disukai. Seperti yang disampaikan Informan II dan IV berikut:

"Beda aja gitu, atau mungkin karna emang itu apa cerita jaman dulu kan, itu emang cerita nyata dan itu jaman dulu. Mungkin kar.. mungkin orang-orang jaman dulu ngomongnya kalok nggombalin kayak gitu ya? Nggak ngerti juga aku. Kek beda aja sama orang jaman sekarang, kayak cowokcowok jaman sekarang kayak gombalnya itu-itu aja kayak gitu, ngebosenin. Terus kalau itu tu kek beda gitu" - Husna

"Bahasa ya itu bahasa Sunda apa bahasa Melayu gitu yang biasa dipake buat ngomong sama si Dilan gitu. Terus si Dilan tu tapi kalo ngegombal tu seringnya pake bahasa baku sih sebenernya. Tapi lucu aja gitu. Biasanya kan orang ngegombal tu pakek bahasa sehari-hari gitu kan. Kalo dia itu kayak bahasanya baku banget gitu tapi malah ngena." - Fransisco

Lebih lanjut Informan IV menyampaikan apabila bahasa baku yang biasa digunakan Dilan dalam menyampaikan "gombalan" atau pujian kepada Milea terasa lucu dan berbeda dengan orang-orang yang umumnya mengunakan bahasa sehari-hari yang cenderung tidak baku. Contohnya dalam menyampaikan rasa kangen, alih-alih menggunakan kata 'kangen', Dilan menggunakan kata 'rindu' .

Audiens remaja mengambil makna pemilihan kata yang digunakan Dilan secara umum sesuai dengan apa disandikan dalam pesan yaitu arti harfiah dari kata-kata yang digunakan Dilan. Namun pada waktu yang sama, audiens remaja juga turut memaknainya sebagai sesuatu yang lucu dan beda atau tidak umum dilakukan oleh orang-orang zaman sekarang. Pada posisi ini, audiens memaknai penggunaan kata-kata Dilan dengan mengaitkan konteks zaman dan situasi sosial dimana para audiens berada pada masa sekarang. Maka dari itu, audiens memodifikasi dan menegosiasikan sebagian makna yang dirujuk oleh pesan, tidak hanya arti harfiah sebuah kata-kata tetapi juga konteks kata-kata tersebut jika digunakan untuk bercakap-cakap pada lingkungan sosialnya sekarang.

Pada konteks penggunaan kata-kata eksotisme, para informan berada pada posisi negosiasi. Meski demikian, terdapat pesan keunikan lain dalam romantisme Dilan yang mereka terima dari perilaku Dilan. Antara lain pada adegan Dilan yang memanggilkan tukang pijat untuk Milea yang sedang sakit. Informan I menilai hal tersebut romantis karena jarang ada lelaki yang berperilaku seperti itu.

Para informan menyampaikan keunikan dari perilaku Dilan khususnya pada adegan pemberian buku TTS (Teka-Teki Silang) sebagai 
kado ulang tahun Milea. Hal ini dianggap unik dan tidak biasa karena dibandingkan dengan kado boneka dari ketua kelas. Perilaku unik lainnya yaitu saat Dilan datang ke rumah Milea hanya untuk memberi tahu menu batagor baru yang ada di kantin sekolah, adegan Dilan membagi kerupuk menjadi dua dan meminta Milea untuk menyimpannya, serta adegan Dilan dan Milea menandatangani surat bermaterai untuk meresmikan hubungan pacaran mereka. Seperti salah satunya yang diungkap oleh Informan III hal tersebut merupakan hal yang anti mainstream atau tidak biasa dilakukan orang-orang pada umumnya:

"Pas tanda tangan di materai, itu lucu, kan pacaran kan cuman pacaran doang, itu beda kayak tanda tangan di materai gitu... Anti mainstream." - Sang Ayu

Posisi audiens remaja dalam meresepsi segala tindakan Dilan dalam film Dilan 1990 dalam kaitannya dengan individualisme dan eksotisme berada pada dominant-hegemonic position. Audiens menerima pesan dalam adegan tersebut sebagaimana adegan tersebut disajikan sebagai adegan-adegan inti romantisme individu yang masuk ke dalam perasaan serta dunia mimpi mereka sendiri tetapi juga melakukan pencarian pengalaman emosional yang ada pada dunia eksternal seperti pada unsur individualisme dan eksotisme yang ada pada konsep romantisme Neyos yang dipaparkan oleh Pratiwi, dkk. (2013). Hal ini secara spesifik diterima oleh para audiens remaja dari ekspresi Milea yang selalu tersenyum dan tertawa-tawa merespons perilaku Dilan, serta bagaimana Milea tersenyum ketika memikirkan Dilan saat sedang berjauhan atau sedang berada di rumah saat berbincang di telepon. Maka dari itu, audiens remaja melihat adegan-adegan tersebut sebagai adegan romantis yang menunjukkan rasa suka antara Dilan dan Milea.

Dalam resepsi pemaknaan individualisme dan eksostisme yang terkadung dalam romantisme film Dilan 1990, audiens remaja berada pada dua posisi yaitu dominanthegemonic position dan negotiated position. Dominat-hegemonic position pada penerimaan pesan visual perilaku tokoh dan negotiated position pada penerimaan teks kata-kata tokoh. Kedua posisi ini dapat berbeda dikarenakan audiens remaja tetap melihat perilaku-perilaku Dilan sebagai bentuk dari romantisme seorang laki-laki kepada perempuan meskipun dinilai anti-mainstream. Sedangkan kata-kata yang digunakan Dilan dan melakukan pujian kepada Milea dirasa unik, tetapi tidak berarti sepenuhnya romantis karena dinilai katakata tersebut memang dipakai dalam konteks latar waktu tahun 1990-an, bukan pada masa sekarang. Keseluruhan posisi audiens remaja terhadap pesan romantisme yang terkandung dalam film Dilan 1990 terangkum pada tabel 1. 
Tabel 1 Posisi Audiens Remaja terhadap Pesan Romantisme dalam Film Dilan 1990

\begin{tabular}{lccc}
\hline Pesan Romantisme & \multicolumn{3}{c}{ Posisi Audiens Remaja } \\
\cline { 2 - 4 } & Dominant & Negotiated Position & Oppositional Position \\
& Hegemonic Position & & \\
\hline Kembali ke Alam & - & $\sqrt{ }$ & - \\
Melankolis & $\sqrt{ }$ & - & - \\
Primitivisme & $\sqrt{ }$ & - & - \\
Sentimentalis & $\sqrt{ }$ & - & - \\
Eksotisme & $\sqrt{ }$ & $\sqrt{ }$ & - \\
\hline
\end{tabular}

Sumber: Hasil Penelitian, 2020

Dari hasil penelitian ini, dapat dijelaskan mengenai perbedaan interpretasi audiens atas paparan pesan media Film Dilan 1990 sebagai bentuk evaluasi atas pesan komunikasi massa film yang diterima audiens. Selain itu, dalam penelitian ini diketahui posisi remaja sebagai audiens aktif dalam menerima pesan media dengan menggunakan teori resepsi audiens. Posisi audiens remaja terhadap pesan romantisme dalam film Dilan 1990 ini berada pada dua posisi yakni dominant-hegemonic position dan negotiated position. Dua posisi ini menunjukkan bahwa audiens remaja menerima pesan romantisme dalam film Dilan 1990 sesuai dengan yang disampaikan atau direpresentasikan dalam film tersebut. Meskipun demikian, audiens remaja tetap secara aktif melakukan negosiasi atas pesan-pesan yang menurut mereka tidak terdapat korelasi dengan referensi pengalaman hidup mereka.

\section{SIMPULAN}

Penelitian ini dilakukan dengan tujuan untuk mengetahui resepsi dari remaja dengan latar belakang kebudayaan yang berbeda sebagai audiens aktif film Dilan 1990. Dari hasil penelitian dapat diketahui beberapa pemaknaan inti audiens remaja terhadap romantisisme dalam film Dilan 1990 meliputi 'Bandung sebagai Kota Romantis', 'Tangisan Tokoh sebagai Wujud Kemurungan', 'Rindu itu Berat', 'Rasa Suka yang Meluap', dan 'Romantisme Unik dalam Kata-kata Tokoh'. Pemaknaan romantisme yang dibangun dari suasana keadaan alam sebagai latar penceritaan yang mendukung perasaan hari karakter dalam cerita secara spesifik dimaknai oleh audiens dari lokasi kota Bandung yang dinilai sebagai kota yang romantis.

Pemaknaan romantisme oleh audiens remaja dilihat dari suasana 'kemurungan' yang ditampilkan dalam film. Pemaknaan audiens atas kemurungan tersebut dilihat dari adegan tangisan tokoh dalam cerita. Dalam 
pemaknaan unsur romantisme alam dimana Bandung disimpulkan sebagai Kota Romantis, para informan berada pada posisi negotiated. Pada posisi ini, informan mengambil makna secara umum seperti disandikan dalam pesan, yaitu Bandung sebagai kota sentral romantis, tetapi informan memodifikasi atau mengubah sebagian makna yang dirujuk oleh pesan.

Pemaknaan romantisme dari unsur primitivisme yang paling menonjol dalam pemaknaan para informan adalah perasaan kerinduan yang diekspresikan para tokoh di dalam film. Hal ini ditekankan pada salah satu dialog tokoh yaitu "Rindu itu berat" sebagai salah satu ciri khas unik yang ada dalam film Dilan 1990. Dalam pemaknaan primitivisme, kerinduan para informan di sini menunjukkan posisi audiens remaja pada posisi yang sama dengan kerangka interpretasi yang ditawarkan cerita yaitu dominant-hegemonic position

Pemaknaan romantisme audiens remaja dalam unsur sentimentalis, yakni aspek 'Rasa Suka yang Meluap'. Romantisme film ditunjukkan dari ungkapan emosi tokoh secara berlebihan atas sesuatu yang disukai dengan penggunaan kata-kata puitis dan perilaku pendukung lainnya. Posisi audiens pada penerimaan pesan adegan ini berada pada dominant-hegemonic position. Audiens meresepsi segala emosi rasa sayang yang meluap antara Dilan dan Milea sebagaimana gejolak percintaan antara kedua tokoh tersebut terbangun dalam film.

Para informan dalam penelitian ini memaknai romantisme dalam film Dilan sebagai romantisme yang unik. Keunikan dalam romantisme Dilan dimaknai oleh para informan khususnya pada kosa kata yang digunakan Dilan dalam mengungkapkan kalimat "gombalan" atau pujian yang ditujukan untuk membuat Milea senang. Pemaknaan informan atas penggunaan kata-kata Dilan yang terasa unik, tetapi juga terasa beda dan lucu menunjukkan bahwa audiens remaja di sini berada pada posisi negotiated position. Meskipun audiens remaja merasakan keunikan atas eksotisme kata-kata Dilan, audiens remaja melihatnya sebagai sesuatu yang lucu dan berbeda dengan kata-kata yang umumnya digunakan seseorang ketika melakukan "gombalan" atau pujian kepada seseorang yang disukai. Selain itu, posisi audiens remaja dalam meresepsi segala tindakan Dilan dalam film Dilan 1990 dalam kaitannya dengan individualisme dan eksotisme berada pada dominant-hegemonic position. Audiens menerima pesan dalam adegan tersebut sebagaimana adegan tersebut disajikan sebagai adegan-adegan inti romantisme individu yang masuk ke dalam perasaan serta dunia mimpi mereka sendiri tetapi juga melakukan pencarian pengalaman emosional yang ada pada dunia eksternal. 
Hasil penelitian yang menunjukkan perbedaan posisi audiens aktif dalam menerima pesan Film Dilan 1990 memberikan evaluasi atas pesan komunikasi massa film yang diterima audiens. Selain itu, penelitian ini menjadi sebuah kajian dalam konteks komunikasi massa yang spesifik pada kajian terhadap audiens.

Penelitian mengenai analisis resepsi remaja terhadap film Dilan 1990 ini terbatas pada audiens remaja di bangku SMA sehingga penelitian resepsi audiens semacam ini masih dapat dikembangkan lagi dengan target informan dengan karakteristik yang berbeda. Selain itu, hasil penelitian ini menjadi dasar informasi dan pengetahuan bagi masyarakat bahwa dalam aktivitas konsumsi media, masyarakat memiliki kemampuan penerimaan pesan yang berbedabeda. Untuk itu, dalam hal kaitannya dengan resepsi pesan romantisme yang ada dalam film, orang tua pada khususnya dapat melakukan pendampingan pada anak remaja dalam proses konsumsi media tersebut.

\section{DAFTAR PUSTAKA}

Abdullah, A., \& Permana, R. S. M. (2020). Pembingkaian media mengenai "Sudut Dilan" yang terinspirasi Film Dilan 1990 dan 1991. ProTVF, 4(1), 85-104. https:// doi.org/10.24198/ptvf.v4i1.24184

Alit, T. (2018). Kumpulan Plesetan Poster Film Dilan Yang Ga Kalah Keren! viral.id. http://www.viral.id/entertainment/652415/ Kumpulan-Plesetan-Poster-Film-Dilan-
Yang-Ga-Kalah-Keren

Amalia, S. (2018, Januari 14). 10 Pelesetan Obrolan Dilan \& Milea Ini Gagal Romantis Malah Ngakak. idntimes.com. https://www. idntimes.com/hype/humor/sita-amalia/10pelesetan-obrolan-dilan-dan-milea-inigagal-romantis-malah-bikin-ngakak-1/1

Briandana, R. (2016). Televisi Berlangganan dan Identitas Diri: Studi Resepsi Remaja terhadap Tayangan Drama Seri Korea Decendents Of The Sun di KBS World. Jurnal Simbolika, 2(1). https://doi. org/10.31289/simbollika.v2i1.217

Davis, H. (2004). Understanding Stuart Hall. SAGE Publications. http://www.ebrary. com

Driesmans, K., Vandenbosch, L., \& Eggermont, S. (2016). True love lasts forever: The influence of a popular teenage movie on Belgian girls' romantic beliefs. Journal of Children and Media, 10(3), 304-320. https://doi.org/10.1080/17482798.2016.11 57501

Efsa, N. W. (2015). Manifestasi Ideologi Romantik dalam Puisi-Puisi Acep Zamzam Noor. LITERA, 14(1), 187-204. https://doi. org/10.21831/ltr.v14i1.4417

Fais, F., Sudaryanto, E., \& Andayani, S. (2019). Persepsi Remaja pada Romantisisme Film Dilan 1990. representamen, 5(1). https://doi.org/10.30996/representamen. v5i1.2397

Fathurizki, A., \& Malau, R. M. U. (2018). Pornografi dalam film: analisis resepsi film "men, women \& children." ProTVF, 2(1), 19-35. https://doi.org/10.24198/ptvf. v2i1.11347

Film Indonesia. (2018). Data penonton tahun 2018. http://filmindonesia. or.id/movie/viewer/2018\#.X_T1dOkzbpA Fitrianingsih, E., \& Nazaruddin, K. (2017). 
Romantisme pada Novel Soekarno Kuantar ke Gerbang karya Ramadhan K.H dan Implikasinya. Jurnal Kata (Bahasa, Sastra, dan Pembelajarannya).

Gumelar, E. (2018). Analisis Resepsi Film Tanda Tanya. Interaksi Online, 1(1), Article 1. https://ejournal3.undip.ac.id/index.php/ interaksi-online/article/view/1543

Hardyanti, W. (2019). Penerimaan Khalayak Terhadap Tayangan Infotainment Tentang Fenomena Artis Lepas Jilbab (Studi Pada Mahasiswi Muslimah di Malang Berdasarkan Kelompok Sosial). ARISTO, 7(2), 296. https://doi.org/10.24269/ars. v7i2.1757

Jensen, K. B. (2013). A Handbook of Media and Communication Research: Qualitative and Quantitative Methodologies. Taylor and Francis. http:/grail.eblib.com.au/patron/ FullRecord.aspx? $\mathrm{p}=170177$

Johnson, K. R., \& Holmes, B. M. (2009). Contradictory Messages: A Content Analysis of Hollywood-Produced Romantic Comedy Feature Films. Communication Quarterly, 57(3), 352-373. https://doi. org/10.1080/01463370903113632

Juniawati, A., Priyadi, A. T., \& Seli, S. (2019).
Struktur dan Romantisme dalam Kumpulan Cerpen Kidung Kampung Berdebu Karya Saifun Arif Kojeh. Jurnal Pendidikan dan Pembelajaran Khatulistiwa, 8(11).

Pratiwi, I., Baruadi, M. K., \& Muslimin. (2013). Romantisme dalam Novel Kerudung Mereh Kirmizi karya Remy Sylado.

Stevenson, N. (2002). Understanding Media Cultures Social Theory and Mass Communication (2nd ed.). SAGE.

Vaterlaus, J. M., Tulane, S., Porter, B. D., \& Beckert, T. E. (2018). The Perceived Influence of Media and Technology on Adolescent Romantic Relationships. Journal of Adolescent Research, 33(6), 651-671. https://doi. org/10.1177/0743558417712611

Wolfson, S. J. (2014). Romanticism \& Gender \& Melancholy. Studies in Romanticism, 53(3), 435-456. https://doi.org/10.1353/ srm.2014.0007

Yoo, E. E., \& Buzinde, C. N. (2012). Gazing Upon The Kingdom: An Audience Reception Analysis of a Televised Travelogue. Annals of Tourism Research, 39(1), 221-242. https://doi.org/10.1016/j. annals.2011.06.002 